\title{
RESEARCH ON HEAVE PLATE EFFECT ON VERTICAL COLUMN MOTION
}

\author{
Ionut-Cristian SCURTU ${ }^{1}$ \\ Adrian POPA ${ }^{2}$ \\ Marian RISTEA ${ }^{3}$ \\ Daniel MARASESCU ${ }^{4}$
}

${ }^{1}$ Principal Instructor, PhD Eng. "Mircea cel Batran" Naval Academy

${ }^{2}$ Assist prof. PhD Eng. "Mircea cel Batran" Naval Academy

${ }^{3}$ Assist. prof. PhD. Eng., Marine Engineering and Naval Weapons Department, "Mircea cel Batran" Naval Academy

${ }^{4} \mathrm{PhD}$ attendee "Mircea cel Batran" Naval Academy, Marine Engineering and Naval Weapons Department

\begin{abstract}
Difficulties in 3D models simulation related to large number of cells and nodes lead to higher hardware requirements and large sets of equations for solving VoF model in CFX solver. To simplify the computational load we will use only one column vertical cross section because the vertical motion will determine effect of heave plates due to increased additional mass. Simplified Computational Fluid Dynamics(CFD) lead to fast simulation results and realistic vertical motion analysis. The column is fitted with heave plate and during the vertical motion simulation the angle of incidence between freesurface and column will be modified as a set parameter. Based on Ansys CFX software and VoF method the column will be submerged in saltwater and released with an excess of buoyancy equivalent to 0,4 meters movement of COG. Graphical results are presented for simulated situations and all results show
\end{abstract}

Keywords: heave plate; wave response, vertical motion, Ansys VoF.

\section{Introduction}

A seakeeping analysis is required in the design and concept process for all floating structures. In the present study using dimension from WindFloat semisubmersible, presented in fig.1., a single floater cylinder equipped with heave plate will be analised with VoF method in order to present vertical motin. The Ansys parametric simulation will modify the vertical angle of the column fitted with heave plate to quantify added mass influence.

Semisubmersibles are designed to face environmental loads and to get the best response required for project purposes. A single column analysis can validate vertical motion for different incident angles.

In case of a triangular shaped [2] semisubmersible (fig.1.), part of WindFloat project, the seakeeping characteristics are modified due to truss interaction. First assumption is that the vertical cylinder is floating without restrictions from mooring system or other structural elements.

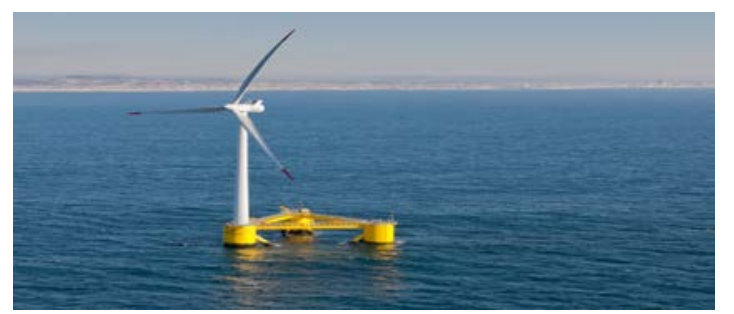

Fig.1. WindFloat real project for wind turbines

The present study will present vertical motion response for a single column fitted with heave plates in. In Vof method available in Ansys CFX simulations five degrees of freedom are restricted in order the vertical motion. Shapes and sizes for each cylinder are used in Modelmaker from ASC to compute the 3D shape of the windfloat semisubmersible presented in fig. 2 and 3 . The column from Modelmaker project will be analyzed in a 2D and 3D model via Ansys CFX.

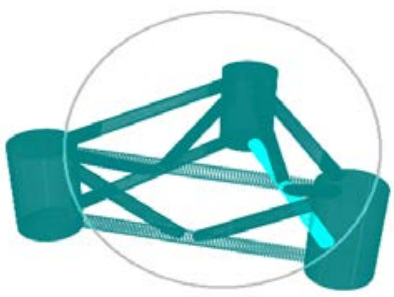

Fig.2. Triangular shaped semisubmersible in Modelmaker 
"Mircea cel Batran" Naval Academy Scientific Bulletin, Volume XIX - 2016 - Issue 2

The journal is indexed in: PROQUEST / DOAJ / Crossref / EBSCOhost / INDEX COPERNICUS / DRJI / OAJI I JOURNAL INDEX / I2OR / SCIENCE LIBRARY INDEX / Google Scholar / Academic Keys/ ROAD Open Access I Academic Resources / Scientific Indexing Services I SCIPIO I JIFACTOR

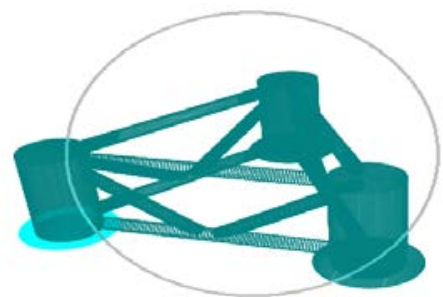

Fig.3. Triangular shaped semisubmersible with heave plates in Modelmaker

\section{Ansys geometry and mesh}

Ansys CFX software has capabilities in evaluating multiphase flows for all geometry shapes based on a 2D or 3D model. The schematic of the CFX project is presented in fig.4. All geometrical values can be used as parameters for Ansys parametric setup. In the present work the parameter used in Parameter Set (presented below) is the angle between cylinder axis and the vertical axis.

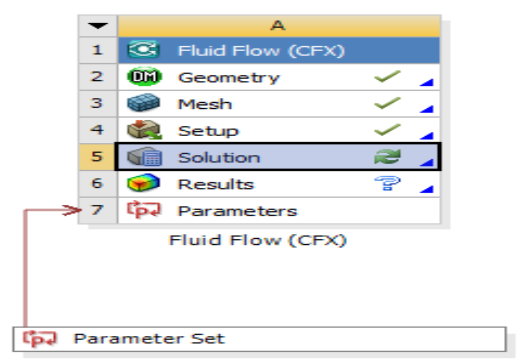

Fig.4. CFX program parametric setup

The cross section of the vertical column realized in Geometry component is presented in fig. 5 with vertical axis (blue vertical line) and dimensions L3, $\mathrm{H} 1, \mathrm{H} 2$, and H3(all dimensions can be parameterized).

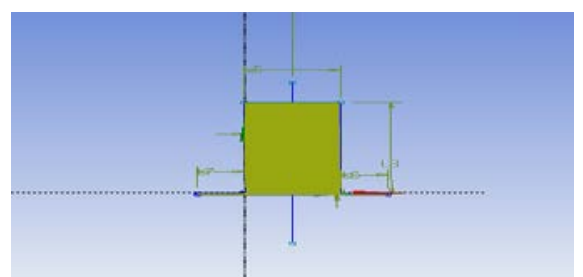

Fig.5. One column in vertical position

The angle between vertical axis and cylinder axis is used for parametric setup and parametric analysis. Valus used in simulation are 30, 45 and 60 . All situations are presented below in figures 6,7 and 8.

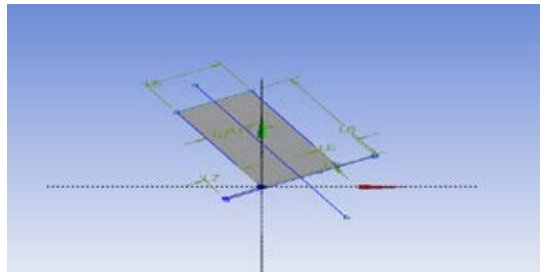

Fig.6. One column inclined 30 degrees

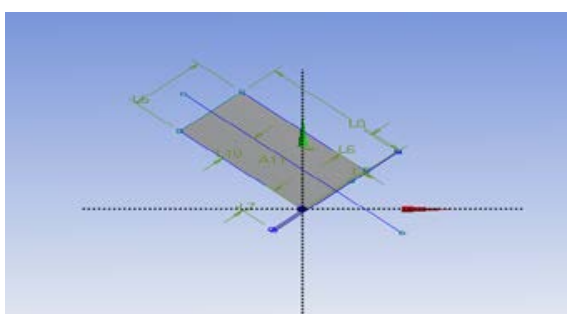

Fig.7. One column inclined 45 degrees

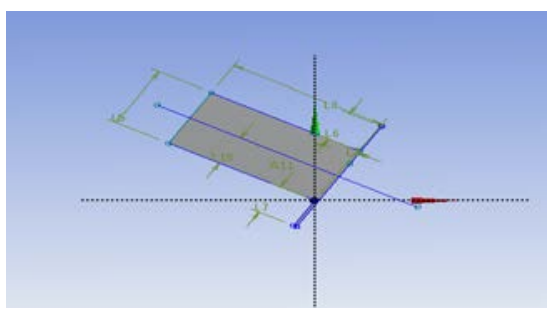

Fig.8. One column inclined 60 degrees

The CFX solver requires a mesh in order to continue to setup, mesh that can be done automatically or using a specific method related to results and solver capabilities. In the presented work we used patch conforming method and in mesh size a defined maximum element length. Results from mesh are presented in fig. 9.

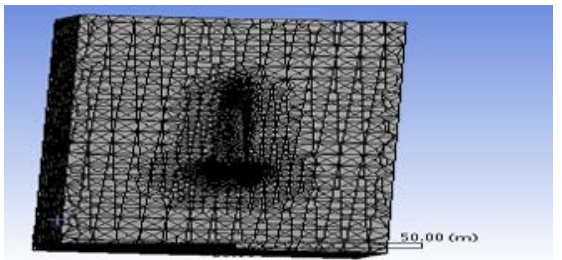

Fig.9. Mesh for one column analysis

Details around heave plate are presented below in fig. 10 for an angle of 30 degrees.

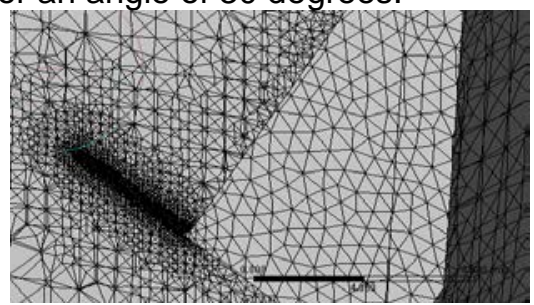

Fig.10. Detailed mesh for one column analysis 


\section{"Mircea cel Batran" Naval Academy Scientific Bulletin, Volume XIX - 2016 - Issue 2 \\ The journal is indexed in: PROQUEST / DOAJ / Crossref / EBSCOhost / INDEX COPERNICUS / DRJI / OAJI I JOURNAL INDEX / I2OR / SCIENCE LIBRARY INDEX / Google Scholar / Academic Keys/ ROAD Open Access I Academic Resources / Scientific Indexing Services / SCIPIO / JIFACTOR}

\section{The VOF Model general description}

The VOF model can model two or more immiscible fluids by solving a single set of momentum equations and tracking the volume fraction of each of the fluids throughout the domain using Navier-Stokes (NS) and a parameter volume of fraction. Typical simulations include the prediction of jet breakup, the motion of large bubbles in a liquid, the motion of floating objects, and the steady or transient tracking of any liquid-gas interface. The VOF model is a surface-tracking technique applied to a fixed Eulerian mesh. It is designed for two or more immiscible fluids where the position of the interface between the fluids is of interest. In case of floating objects, the interface of interest is the freesurface. In the VOF model, a single set of momentum equations is shared by the fluids, and the volume fraction of each of the fluids in each computational cell is tracked throughout the domain.

\section{VoF method in CFX modelling}

\section{The VOF formulation}

The VOF formulation in CFX is generally used to compute a time-dependent solution, but for problems related to vertical motion this will lead to a large set of equations, values and a large amount of memory required.

If you are concerned only with a steady-state solution, it is possible to perform a steady-state calculation in VoF method.

The VOF formulation relies on the fact that two or more fluids (or phases) are not interpenetrating in the simulation created a water/air interface is used. For each additional phase that you add to your model, a variable is introduced: the volume fraction of the phase in the computational cell and his will increase amount of CPU calculation with 1.25 for each phase.. In each control volume, the volume fractions of all phases sum to unity in order to verify VoF method for floating objects. The fields for all variables and properties are shared by the phases and represent volumeaveraged values, as long as the volume fraction of each of the phases is known at each location in the domain of water and air.

Applications of the VOF model include floating objects, stratified flows, free-surface flows, filling, sloshing, the motion of large bubbles in a liquid, the motion of liquid after a dam break, the prediction of jet breakup(surface tension), and the steady or transient tracking of any liquid-gas interface.

\section{Time Dependence of VoF calculations}

For time-dependent VOF calculations results can show vertical motion history, forces history, torque history. This is solved using an explicit timemarching scheme inside VoF method. CFX automatically refines the time step in default setup for the integration of the volume fraction equation, but you can influence this time step calculation with specific value. You can choose to update the volume fraction once for each time step, or once for each iteration within each time step. These options are used for small scale phenomena around bodies surrounded by two phases or a mixture.

\section{Temporarily Ignoring Lift and Virtual Mass} Forces for fast solution

Lift and Virtual Mass Forces are very important to objects placed in a two phase domain especially when phase flow or object movement is involved. Difficulties in reduced stability and numerical errors can be avoided in the calculation by temporarily ignoring the action of the lift and the virtual mass forces. Once the solution without Lift and Virtual Mass Forces starts to converge, you can interrupt the calculation, define these forces appropriately, and continue the calculation.

Calculation through parametric angle in geometry

VoF method can be used in both 2D and 3D simulations and results can be plotted in different ways: streamline for 2D (fig.11), contour for 2D of pressure (fig.12), and contour for 2D of Eddy (fig.13). Results in solver are presented with izosurface for fraction value 0.5 if free surface required.

Initial setup of VoF method is done using a difference between weight and buoyancy corresponding to a 0.4 meters Centre of gravity movement. Simulations are carried out for two similar models with or without heave plate for different angles (30, 45 and 60).

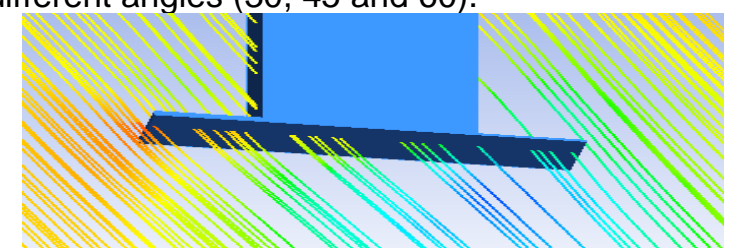

Fig.11. Streamlines contours around 2D column in vertical motion

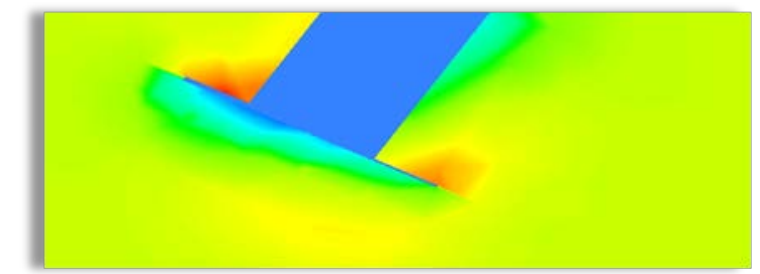

Fig.12. Pressures contours around 2D column in vertical motion 
"Mircea cel Batran" Naval Academy Scientific Bulletin, Volume XIX - 2016 - Issue 2 The journal is indexed in: PROQUEST / DOAJ / Crossref / EBSCOhost / INDEX COPERNICUS / DRJI / OAJI / JOURNAL INDEX / I2OR / SCIENCE LIBRARY INDEX / Google Scholar / Academic Keys/ ROAD Open Access I Academic Resources / Scientific Indexing Services / SCIPIO I JIFACTOR

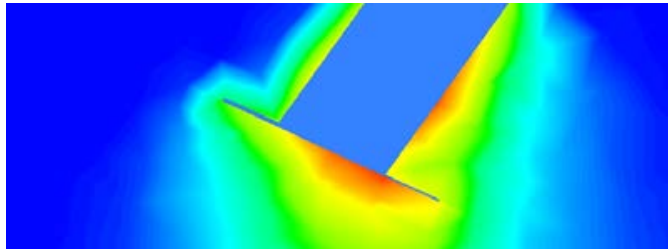

Fig.13. Eddy contours around simple column in vertical motion

\section{Results}

VoF method simulation results for a vertical cylinder (used in Windfloat project fitted/not fitted with heave plate) are presented below is also presented graphically in fig. 18-23. Relevant data like maximum vertical position and positions for equilibrium between weight and buoyancy are collected in table no.1.

The solution is convergent in all studied cases and initial conditions and boundaries there cases are identical.

Table 1.Results table for VoF method

\begin{tabular}{|c|c|c|c|c|c|c|c|c|}
\hline & \multicolumn{4}{|c|}{ Cylinder } & \multicolumn{4}{|c|}{$\begin{array}{l}\text { Cylinder with heave } \\
\text { plate }\end{array}$} \\
\hline 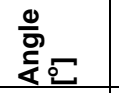 & 0 & 30 & 45 & 60 & 0 & 30 & 45 & 60 \\
\hline 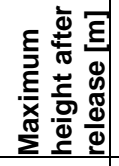 & $\begin{array}{l}0 \\
2 \\
2 \\
5\end{array}$ & $\begin{array}{c}0.2 \\
2\end{array}$ & $\begin{array}{c}0.2 \\
0\end{array}$ & $\begin{array}{c}0.1 \\
8\end{array}$ & $\begin{array}{c}0.1 \\
9\end{array}$ & $\begin{array}{c}0.1 \\
8\end{array}$ & $\begin{array}{c}0.1 \\
7\end{array}$ & $\begin{array}{c}0.1 \\
8\end{array}$ \\
\hline 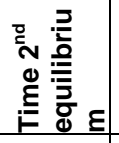 & $\begin{array}{l}4 \\
5\end{array}$ & 4.5 & 4.4 & & 4.2 & 4.2 & 4.3 & 4.4 \\
\hline 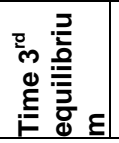 & $\begin{array}{l}7 \\
0\end{array}$ & 6.4 & 5.6 & 11 & 5.8 & 6.1 & 5.8 & 11 \\
\hline
\end{tabular}

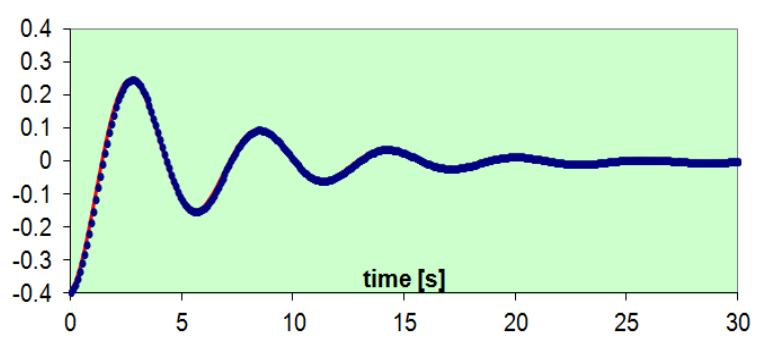

Fig.18. Vertical cylinder motion

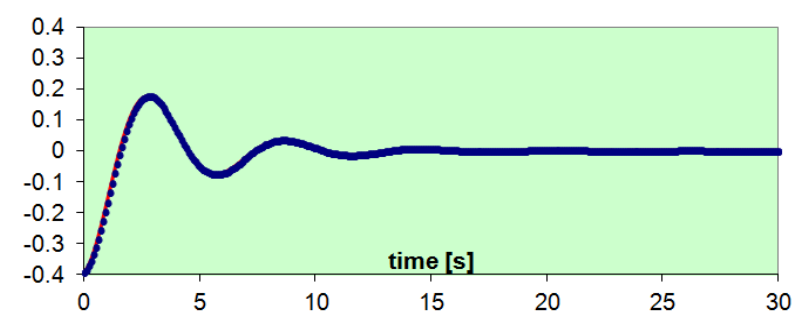

Fig.19. Vertical cylinder with heave plate motion

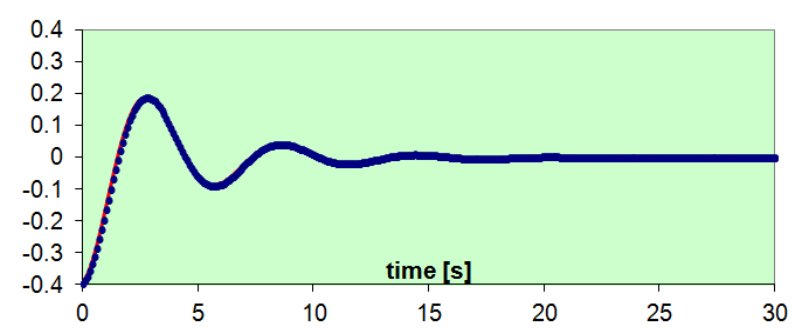

Fig.20. Cylinder motion at 45 degrees

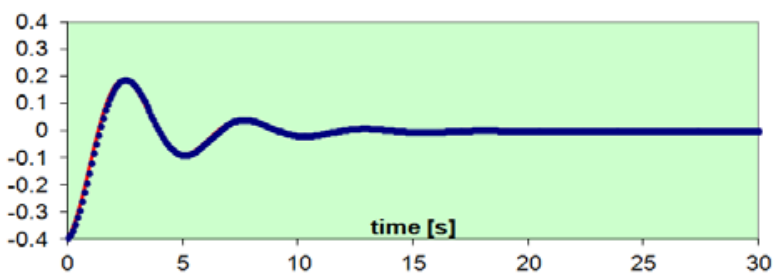

Fig.21. Cylinder with heave plate motion at 45 degrees

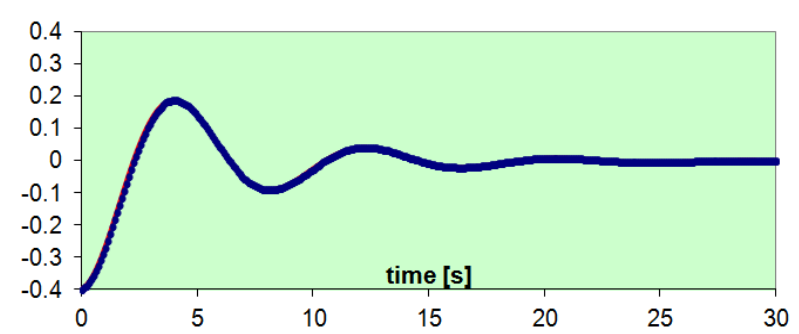

Fig.22. Cylinder motion at 60 degrees

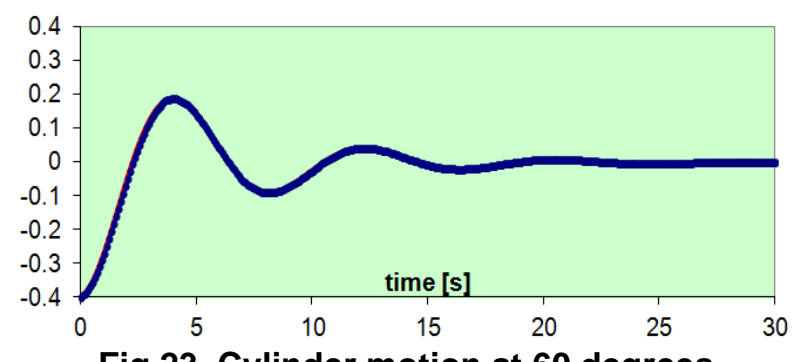

Fig.23. Cylinder motion at 60 degrees

\section{CONCLUSIONS}

A VOF method is a powerful tool for investigating floating bodies and CoG motion. Motion of CoG in VoF method analysis is presented and heave plate effect is visible during recorded steps. 
"Mircea cel Batran" Naval Academy Scientific Bulletin, Volume XIX - 2016 - Issue 2

The journal is indexed in: PROQUEST / DOAJ / Crossref / EBSCOhost / INDEX COPERNICUS / DRJI / OAJI I

JOURNAL INDEX / I2OR / SCIENCE LIBRARY INDEX / Google Scholar / Academic Keys/ ROAD Open Access I

Academic Resources / Scientific Indexing Services / SCIPIO I JIFACTOR

This work has reviewed and reported the state of art in VoF method simulations for cylinder motion. In this seakeeping analysis we have shown that vertical motion is influenced by heave plate and angle from vertical axis. In VoF method results, based on strong CFX software analysis, present the influence of the heave plate on vertical motion for the column.

At a higher angle value the influence on vertical motion was reduced. This is confirmed by the case when the cylinder in placed horizontally.

\section{BIBLIOGRAPHY}

[1] Faltinsen O.M., Sea Loads on ships and offshore, Cambridge University Press, ISBN 0-521-458706, 1999.

[2] Geun-Nam Lim, Sang-Hyun Kim and Dong-Young Kim, A Numerical Study on the Appendage Shape for a Heave Motion Reduction of Floating Cylindrical Structure, Journal: Journal of the Korean Society of Marine Environment and safety, 2015, Volume 21, Number 4, Page 449,

[3] Jeremiah P., Yucheng Li, Frequency and time domain modeling and power output for a heaving point absorber wave energy converter, International Journal of Energy and Environmental Engineering, July 2014, 5:101

[4] M. Pricop Metoda diferenţelor finite utilizată în calculul stabilităţii plăcilor plane, publ. în Proc. Sesiunea jubiliară de comunicări ştiinţifice cu participare internaţională, Academia Navală Mircea cel Bătrân, Constanţa, 2002

[5] Oncica V. , Pricop M., Chiţac V., Zus M., Influenţa formelor navei şi a adâncimii apei sub chilă asupra vibraţiilor verticale ale grinzii navă de secţiune constantă, A XIX a Sesiune de comunicări ştiinţifice cu participare internaţională NAV-MAR-EDU 2005, Constanţa,.

[6] Pricop M., Vibraţiile corpului navei sub acţiunea hidrodinamică a forţelor şi momentelor din valurile regulate, A XXVIII a Sesiune de Comunicări Ştiinţifice cu Participare Internaţională din Academia Tehnică Militară 21-22 octombrie 1999, Bucureşti, p 206-215

[7] Shivaji T. Ganesan, Debabrata Sen, Time-domain simulation of large-amplitude wave-structure interactions by a 3D numerical tank approach, Journal of Ocean Engineering and Marine Energy, August 2015, Volume 1, Issue 3, pp 299-324. 